\title{
CATALYTIC HYDROGENATION OF CARBON MONOXIDE
}

DOE/ER/ 13615--6

Technical Report - Research Progress Report

DE92 014729

December 15, 1991 - December 14, 1992

Grant No. DE-FG02-86-ER13615

Principal Investigator: Dr. Bradford B. Wayland

Grantee: The Trustees of the University of Pennsylvania

Philadelphia, Pennsylvania 19104

\section{NOTICE}

This report was prepared as an account of work prepared by the United States

Government. Neither the United States nor the Department of Energy, nor any of their employees, nor ary of their contractors, subcontractors, or their employees, make any warranty, express or implied, or assumes any liability of responsibility for the accuracy, completeness, or usefulness of any information, apparatus, product or process disclosed or represents that its use would not infringe privately-owned rights.

December, 1992

Prepared for

The U.S. DEPARTMIENT OF ENERGY

AGREEMENT NO. DE-FG02-86ER 13615 


\title{
TECHNICAL REPORT
}

\author{
Grant No. DE-FG02-86ER 13615
}

Budget period: $12 / 15 / 91-12 / 14 / 92$

Project period: $12 / 15 / 89-12 / 14 / 92$

Project Title: Catalytic Hydrogenation of Carbon Monoxide

\begin{abstract}
This project is focused on developing strategies to accomplish the reduction and hydrogenation of carbon monoxide to produce organic oxygenates at mild conditions. Our approaches to this issue are based on the recognition that rhodium macrocycles have unusually favorable thermodynamic values for producing a series of intermediates implicated in the catalytic hydrogenation of $\mathrm{CO}$. Observations of metalloformyl complexes produced by reactions of $\mathrm{H}_{2}$ and $\mathrm{CO}$, and reductive coupling of $\mathrm{CO}$ to form metallo $\alpha$-diketone species have suggested a multiplicity of routes to organic oxygenates that utilize these species as intermediates. Thermodynamic and kinetic-mechanistic studies are used in constructing energy profiles for a variety of potential pathways, and these schemes are used in guiding the design of new metallospecies to improve the thermodynamic and kinetic factors for individual steps in the overall process. Variation of the electronic and steric effects associated with the ligand arrays along with the influences of the reaction medium provide the chemical tools for tuning these factors. Emerging knowledge of the factors that contribute to $\mathrm{M}-\mathrm{H}, \mathrm{M}-\mathrm{C}$ and $\mathrm{M}-\mathrm{O}$ bond enthalpies is directing the search for ligand arrays that will expand the range of metal species that have favorable thermodynamic parameters to produce the primary intermediates for $\mathrm{CO}$ hydrogenation. Studies of rhodium complexes are being extended to non-macrocyclic ligand complexes that emulate the favorable thermodynamic features associated with rhodium macrocycles, but that also manifest improved reaction kinetics. Multifunctional catalyst systems designed to couple the ability of rhodium complexes to produce formyl and diketone intermediates with a second catalyst that hydrogenates these intermediates are promising approaches to accomplish $\mathrm{CO}$ hydrogenation at mild conditions.
\end{abstract}


Research Progress Report

Our research during the prior project period has been divided between developing a fundamental understanding of the $\mathrm{CO}$ reductive coupling process observed for rhodium(II) porphyrins and an attenuated continuing effort in exploring the formation and reactivity of metalloformyl species.

\section{1) Porphyrin Ligands: Variation of Ligand Steric Requirements}

Systematic variation of porphyrin ligand steric demands has been used in tuning the effective $\mathrm{M}-\mathrm{M}$ and $\mathrm{M}-\mathrm{C}$ bond enthalpies which are important factors in determining the scope and thermodynamic selectivity in forming the organometallic species pertinent to this proposal. A list of porphyrin ligands arranged in the order of increasing steric demands is given below along with abbreviated names used throughout the proposal.

porphyrin name

Octaethylporphyrin

Tetraphenylporphyrin

Tetra(3,5-dimethylphenyl) porphyrin

Tetra(2,4,6-trimethylphenyl) porphyrin (Tetramesitylporphyrin)

Tetra(2,4,6-triethylphenyl) porphyrin

Tetra(2,4,6-triisopropylphenyl) porphyrin symbol

OEP

TPP

TXP

TMP

TTEPP

TTiPP

Rhodium(II) and Iridium(II) porphyrin and related macrocycle complexes usually occur as metal-metal bonded dimers. When substituents with increasing steric demands are incorporated on the periphery of the porphyrin the interligand repulsions increase and the effective $M-M$ bond dissociation enthalpy decreases (D[(OEP)Rh $]_{2} \sim 16 \mathrm{kcal} \mathrm{mol}^{-1} ; \mathrm{D}[(\mathrm{TXP}) \mathrm{Rh}]_{2} \sim 12 \mathrm{kcal} \mathrm{mol}^{-1}$;

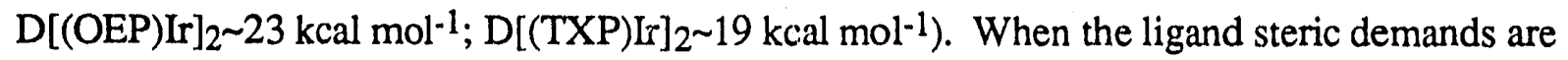
equal to or larger than that for tetramesityl porphyrin (TMP) the Rh(II) porphyrin complex is an $S=1 / 2$ paramagnetic monomer species, (por)Rh. EPR and NMR contact shifts have been used to demonstrate that the odd electron occupies the $\mathrm{d}_{\mathrm{z}} 2$ in (por) $\mathrm{Rh}^{\text {II. }}$ species. (TTiPP)Ir II. is the first example of a stable IrII macrocycle. An interesting feature of this species is that the ${ }^{1} \mathrm{H}$ NMR contact shifts are compatible with the odd electron occupying the $\mathrm{d}_{\mathrm{xz}}$ or $\mathrm{d}_{\mathrm{yz}}$ orbital in contrast with the $d_{z} 2$ occupancy observed for (por) $R h^{\text {Il }}$ species. The use of porphyrin ligand steric demands in tuning the effective $\mathrm{M}-\mathrm{C}$ bond enthalpies is described in the proposal. 


\section{2) One-Electron CO Activation and CO Reductive Coupling}

DOE/ER 13615-6

Activation of $\mathrm{CO}$ is typically accomplished by binding with Lewis acid metal centers which promote two electron reactions with nucleophiles at the carbonyl carbon. ${ }^{24}$ We have recently illistrated an alternate approach to $\mathrm{CO}$ activation through the use of metalloradicals to induce one electron carbonyl reactions. This behavior was first realized in the reactions of octaethylporphyrinato rhodium(II) dimer, $[(\mathrm{OEP}) \mathrm{Rh}]_{2}$, with $\mathrm{CO}$ (equations 1,2$)^{13}$ that produce a dimetal ketone, (OEP)Rh-C(O)- $\mathrm{Rh}(\mathrm{OEP})$, which has precedent in the chemistry of $\mathrm{Pd}(\mathrm{I})$ and $\mathrm{Pt}(\mathrm{I})$ A-frame complexes, ${ }^{25}$ and at higher $\mathrm{CO}$ pressures a dimetal $\alpha$-diketone, (OEP)Rh-C(O)-C(O)$\mathrm{Rh}(\mathrm{OEP})$, which was without precedent. Subsequent studies have shown that sequential increases

1) $[(\mathrm{OEP}) \mathrm{Rh}]_{2}+\mathrm{CO} \rightleftharpoons(\mathrm{OEP}) \mathrm{Rh}-\mathrm{C}(\mathrm{O})-\mathrm{Rh}(\mathrm{OEP})$

2) $[(\mathrm{OEP}) \mathrm{Rh}]_{2}+2 \mathrm{CO} \rightleftharpoons(\mathrm{OEP}) \mathrm{Rh}-\mathrm{C}(\mathrm{O}) \mathrm{C}(\mathrm{O})-\mathrm{Rh}(\mathrm{OEP})$

in porphyrin ligand steric requirements can be used to produce selectivity for $\mathrm{CO}$ reductive coupling $(\mathrm{M}-\mathrm{C}(\mathrm{O})-\mathrm{C}(\mathrm{O})-\mathrm{M})$ and that further increases in the ligand steric demands inhibit the $\mathrm{CO}$ coupling and permit direct observation of seventeen-electron mono CO complexes, [(por)Rh$\mathrm{CO}] \cdot{ }^{14-16}$ Kinetic and thermodynamic studies for the dimerization of the tetramesitylporphyrin derivative, (TMP) Rh-CO, to form (TMP) Rh- $\mathrm{C}(\mathrm{O})-\mathrm{C}(\mathrm{O})-\mathrm{Rh}(\mathrm{TMP})$ provide information on the nature of the 17-electron monocarbonyl and on the $\mathrm{CO}$ reductive coupling reaction. The monocarbonyls, [(por)Rh-CO], are found to have non-linear $\mathrm{Rh}-\mathrm{CO}$ fragments and to react like acyl radicals in dimerizing through $\mathrm{C}-\mathrm{C}$ bonding and in reactions with styrene and sources of hydrogen atoms. ${ }^{16}$

\section{a) Porphyrin Ligand Steric Effects on the Reactions of Rhodium(II) Porphyrins with CO:}

Rhodium(II) porphyrins are unusual in fulfilling the thermodynamic requirements to chemically reduce $\mathrm{CO}$ in forming dimetal ketone $(\mathrm{M}-\mathrm{C}(\mathrm{O})-\mathrm{M})$ and dimetal $\alpha$-diketone $(\mathrm{M}-\mathrm{C}(\mathrm{O})-\mathrm{C}(\mathrm{O})-\mathrm{M})$ complexes. Formation of a dimetal $\alpha$-diketone in equilibrium with a dimetal ketone has particularly demanding thermodynamic criteria, because in addition to the need for relatively large absolute $\mathrm{M}-\mathrm{C}$ bond energies $\left(\sim 4 \mathrm{kcal} \mathrm{mol}^{-1}\right)$, the effective $\mathrm{M}-\mathrm{C}$ bond energy in the $\alpha$-diketone must exceed that in the metalloketone by a minimum of $4-5 \mathrm{kcal} \mathrm{mol}^{-1} .^{13}$ This latter criterion is attainable by rhodium(II) porphyrin complexes because the bent single atom bridged metalloketone species are more sensitive to the steric demands of the porphyrin ligands than the two atom bridged $\mathrm{M}-\mathrm{C}(\mathrm{O})-\mathrm{C}(\mathrm{O})-\mathrm{M}$ complexes where the two porphyrin rings are further apart and capable of attaining a near parallel orientation. Structure simulations given below for (OEP)Rh-C(O)- 
$\mathrm{Rh}(\mathrm{OEP})$ and (OEP) Rh-C(O)C(O)Rh(OEP) illustrate the steric congestion in the dimetal ketone that is relieved in the dimetal diketone.

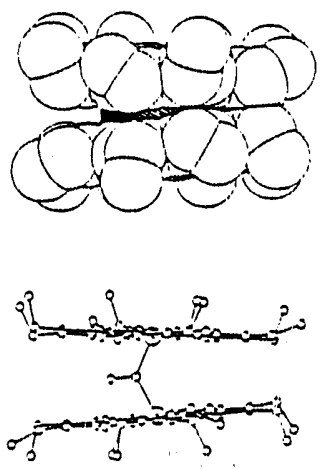

(OEP)Rh-C(O)-Rh(OEP)
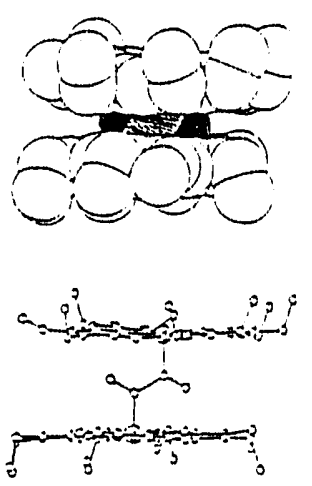

(OEP)Rh-C(O)C(O)-Rh(OEP)

Steric effects are manifested in the equilibrium distribution of $\mathrm{CO}$ containing complexes observed for reactions of $\mathrm{CO}$ with a series of rhodium(II) porphyrin derivatives that have increasing steric demands (OEP $<$ TXP $<$ TMP $<$ TTiPP). In the (OEP)Rh system the metalloketone is the majority species at all conditions studied $\left(\mathrm{P}_{\mathrm{CO}}=0.1-30 \mathrm{~atm} ; \mathrm{T}=220-300 \mathrm{~K}\right)$ in the (TXP)Rh system it is a minority species observed only at low pressure $\left(\mathrm{P}_{\mathrm{CO}}<0.4 \mathrm{~atm} ; \mathrm{T}=\right.$ $298 \mathrm{~K}$ ) and metalloketone species are not observed at any conditions in reactions of CO with (TMP)Rh ${ }^{\circ}$ and (TTiPP)Rh•. Decline in the thermodynamic stability of the metalloketone resulting from increased ligand steric demands in the (TXP)Rh and (TMP)Rh systems is accompanied by dramatic increases in the $\alpha$-diketone species where at $\mathrm{P}_{\mathrm{CO}}=1 \mathrm{~atm}$ and $\mathrm{T}=2.98 \mathrm{~K}$ greater than $99 \%$ of the rhodium porphyrin is incorporated into a $\mathrm{CO}$ reductive coupling product, $(\mathrm{Rh}-\mathrm{C}(\mathrm{O})$ $\mathrm{C}(\mathrm{O})-\mathrm{Rh}$ ). Increasing porphyrin ligand steric demands have thus been used to produce highly selective $\mathrm{CO}$ reductive coupling reactions. Further increase in the ligand steric demands associated with (TTEPP)Rh • and (TTiPP)Rh produce interligand repulsions that inhibit the two-carbon bridged $\alpha$-diketone species and result in observing only the paramagnetic ( $S=1 / 2)$ monocarbonyl complex [(TTiPP)RhCO]•. A monocarbonyl complex, (Rh-CO)•, is unobserved for (OEP)Rh and (TXP)Rh, a minority species with (TMP)Rh• and the exclusive species for the (TTEPP) Rh• and (TTiPP)Rh• systems.

b) One Electron Activation of $\mathrm{CO}$ : Activation of $\mathrm{CO}$ by one electron steps is best known for radicals of the representative elements like methyl radicals which react with $\mathrm{CO}$ to form the transient acetyl radical $\left(\mathrm{CH}_{3} \dot{\mathrm{CO}}\right){ }^{26}$ The acetyl radical is an example of one electron activated $\mathrm{CO}$ 
because it subsequently reacts by a second one electron reaction at the carbonyl carbon to produce acetone, $\left(\mathrm{CH}_{3}\right)_{2} \mathrm{CO}$, and biacetyl, $\mathrm{CH}_{3}-\mathrm{C}(\mathrm{O})-\mathrm{C}(\mathrm{O})-\mathrm{CH}_{3}$. In transition metal chemistry one electron activation of $\mathrm{CO}$ has been accomplished by reduction of 18-electron metal carbonyl complexes to form transient 19-electron species like $\left[(\mathrm{CO})_{4} \mathrm{Fe}-\mathrm{CO}\right]^{\circ-} .27$ One important reaction of 19-electron carbonyl complexes is hydrogen atom abstraction from metal hydrides to form transient 18-electron metalloformyl species $\left(\left[(\mathrm{CO})_{4} \mathrm{Fe}-\mathrm{CO}\right]^{\circ-}+\mathrm{H}-\mathrm{M} \rightarrow(\mathrm{CO})_{4} \mathrm{Fe}-\mathrm{C}(\mathrm{O}) \mathrm{H}+[\mathrm{M} \cdot]\right){ }^{28}$ Comparable reactivity has also been observed for $\left[(\mathrm{CO})_{5} \mathrm{Cr}-\mathrm{CO}\right]^{*-}$, and other 19 electron metallocarbonyl complexes. ${ }^{29}$

Reactions of sterically demanding (TMP)Rh• and (TTiPP)Rh• with CO have resulted in sufficient equilibrium concentrations of the 17-electron monocarbonyl species, [(TMP)Rh-CO]• and [(TTiPP)Rh-CO]•, to permit direct observation by EPR and evaluation of the reactivity patterns for these species. Observation of three $g$ values indicates that the $d_{x z}$ and $d_{y z}$ are non-degenerate which means that these complexes do not have a three fold or higher axis of symmetry. The removal of degeneracy of the $d_{x z}, d_{y z}$ is ascribed to the presence of a non-linear Rh-CO unit which is predicted for the seven-electrons case $\left(d^{7}+\pi^{*} 0\right)$ when the metal and diatomic molecule are capable of relatively strong covalent sigma bonding. ${ }^{30}$ The bent $\mathrm{M}-\mathrm{CO}$ units observed in [(por)RhCO]• complexes are precedented only by nineteen electron complexes like [Fe(CO) 5$]^{*-}$ where the odd electron is required to occupy a predominantly ligand $(\mathrm{CO})$ based orbital. (por)Rh$\mathrm{CO}$ complexes are at present the only examples where a bent $\mathrm{M}-\mathrm{CO}$ unit is induced by effective $\mathrm{M}-\mathrm{CO} \sigma$ bonding.

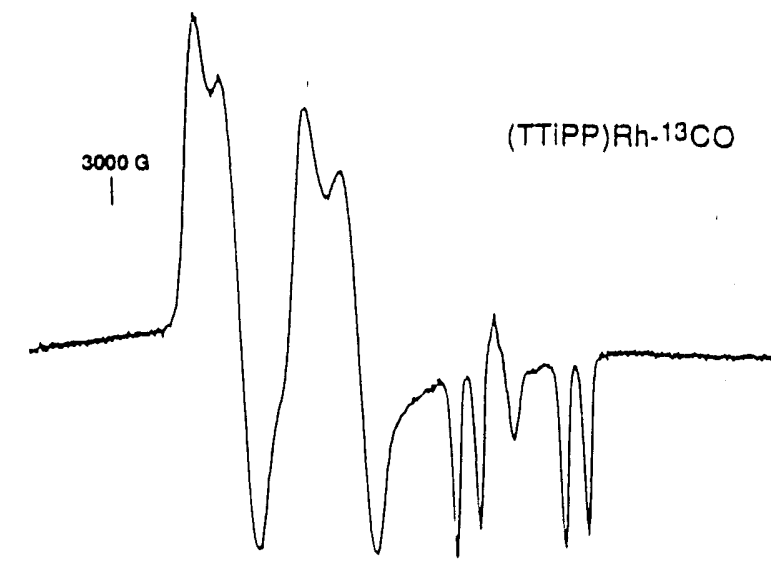

$$
\begin{aligned}
& \text { Frozen solution EPR spectra for (TTiPP)Rh }{ }^{13} \mathrm{CO} \text { in } \\
& \text { toluene glass }(90 \mathrm{~K})\left(\mathrm{g}_{1}=2.167 ; \mathrm{g}_{2}=2.138 ; \mathrm{g}_{3}=\right. \\
& 2.000 ; A\left({ }^{13} \mathrm{C}_{(\mathrm{g})}\right)=318 \mathrm{MHz} ; A\left({ }^{13} \mathrm{C}_{(\mathrm{g} 2)}\right)=347 \mathrm{MHz} ; \\
& \left.A\left({ }^{13} \mathrm{C}_{(\mathrm{g} 3)}\right)=305 \mathrm{MHz} ; A\left({ }^{13} \mathrm{Rh}_{(\mathrm{g} 3)}\right)=65 \mathrm{MHz}\right)
\end{aligned}
$$

Reactions of [(TMP)Rh-CO]• illustrate that this complex mimics acyl radical reactions rather than metal centered radical reactivity. Reversible dimerization of [(TMP)Rh-CO]• through $\mathrm{C}-\mathrm{C}$ bond formation to produce a 1,2 ethanedionyl complex (TMP)Rh-C(O)-C(O)-Rh(TMP) 
DOE/ER 13615-6

(equation 3) illustrates a carbonyl carbon centered one electron reaction that can be viewed as an organometallic analog of acyl radical coupling $(2 R \dot{C} O \rightarrow R-C(O) C(O)-R)$.

3) $2[(\mathrm{TMP}) \mathrm{Rh}-\mathrm{CO}] \bullet \rightleftharpoons(\mathrm{TMP}) \mathrm{Rh}-\mathrm{C}(\mathrm{O}) \mathrm{C}(\mathrm{O})-\mathrm{Rh}(\mathrm{TMP})$

Reaction of [(TMP) Rh-CO] with $(\mathrm{Bu})_{3} \mathrm{Sn}-\mathrm{H}$ to form (TMP) $\mathrm{Rh}-\mathrm{CHO}$ provides an illustration of a metal hydride transferring a hydrogen atom to the carbonyl carbon rather than to the $\mathrm{Rh}$ (II) center (equation 4). Alkenes are known to react rapidly with rhodium(II) porphyrins by radical like

4) $[(\mathrm{TMP}) \mathrm{Rh}-\mathrm{CO}]+\mathrm{HSn}(\mathrm{Bu})_{3} \rightarrow(\mathrm{TMP}) \mathrm{Rh}-\mathrm{CHO}+1 / 2\left(\mathrm{Sn}(\mathrm{Bu})_{3}\right)_{2}$

processes to form alkyl bridged complexes (por) $\mathrm{Rh}-\mathrm{CH}_{2}-\mathrm{CH}(\mathrm{X})-\mathrm{Rh}$ (por). The reaction of styrene with [(TMP)Rh-CO]• provides another opportunity to examine whether the Rh(II) metal based radical $(\cdot \mathrm{Rh}: \mathrm{C} \equiv \mathrm{O}$ :) or acyl radical $(\mathrm{Rh}-\dot{\mathrm{C}}=\mathrm{O})$ nature is manifested. When the equilibrium distribution of (TMP) Rh- $\mathrm{C}(\mathrm{O})-\mathrm{C}(\mathrm{O})-\mathrm{Rh}(\mathrm{TMP})$ and [(TMP)Rh-CO]• is preformed at $\mathrm{CO}$ pressures where virtually all of the (TMP)Rh is reacted $\left(\mathrm{P}_{\mathrm{CO}}>0.3 \mathrm{~atm}\right)$, subsequent reaction with styrene forms (TMP) $\mathrm{Rh}-\mathrm{C}(\mathrm{O}) \mathrm{CH}_{2} \mathrm{CH}\left(\mathrm{C}_{6} \mathrm{H}_{5}\right) \mathrm{C}(\mathrm{O})-\mathrm{Rh}(\mathrm{TMP})$ as the only observed species in the ${ }^{1} \mathrm{H} N M R$ (equation 5).

5) $2[(\mathrm{TMP}) \mathrm{Rh}-\mathrm{CO}] \cdot+\mathrm{CH}_{2}=\mathrm{CHC}_{6} \mathrm{H}_{5} \rightleftharpoons(\mathrm{TMP}) \mathrm{Rh}-\mathrm{C}(\mathrm{O}) \mathrm{CH}_{2} \mathrm{CH}\left(\mathrm{C}_{6} \mathrm{H}_{5}\right) \mathrm{C}(\mathrm{O})-\mathrm{Rh}(\mathrm{TMP})$

Presumably [(TMP)Rh-CO]• interacts with styrene to form an intermediate of the form [(TMP)Rh$\left.\mathrm{C}(\mathrm{O}) \mathrm{CH}_{2} \mathrm{CH}\left(\mathrm{C}_{6} \mathrm{H}_{5}\right)\right] \cdot$ which is trapped by a second [(TMP)Rh-CO]. The styrene reaction is further evidence that [(TMP)Rh-CO]• has a strong preference to function like an acyl rather than a metal based radical.

The electronic structures of [(por)Rh-CO]• species are between the limiting electron structures that localize the odd electron either in the rhodium $\mathrm{d}_{\mathrm{z}} 2(\cdot \mathrm{Rh}: \mathrm{C}=0)$ or on the carbonyl carbon $(\mathrm{Rh}-\dot{\mathrm{C}} \equiv \mathrm{O})$. Results from EPR studies indicate that the odd electron spin density on $\mathrm{CO}$ is $\sim 0.3$. The 17-electron carbonyl complex, (TMP) RhCO, is thus poised for a second one-electron reaction at either the rhodium or carbonyl carbon sites. Reaction of [(TMP)Rh-CO]• with a 1electron species $\mathrm{X}$ - at the metal would produce an 18-electron $\mathrm{Rh}(\mathrm{III})$ carbon monoxide complex, (TMP) $\mathrm{Rh}(\mathrm{X})(\mathrm{CO})$, while reaction at the carbonyl carbon would form a 16-electron $\mathrm{Rh}(\mathrm{III})$ complex, (TMP)RhC(O)X. All of the one-electron radical-like reactions of (TMP)RhCO that have been observed occur at the carbonyl carbon to form 16-electron rhodium(III) complexes. To our knowledge, this reactivity pattern of [(TMP)Rh-CO]• is currently unique among 17-electron metal carbonyls. 


\section{3) Reactions of (TMTAA)Rh Complexes with $\mathrm{H}_{2}, \mathrm{CO}$ and $\mathrm{H}_{2} \mathrm{CO}$}

The rhodium (II) complex of dibenzotetramethyltetraaza [14] annulene (TMTAA) occurs as a $\mathrm{Rh}-\mathrm{Rh}$ bonded dimer, [(TMTAA)Rh]2. [(TMTAA)Rh] $]_{2}$ reacts with $\mathrm{H}_{2}$ to form a hydride complex, (TMTAA)Rh-H, which subsequently reacts with $\mathrm{CO}$ and aldehydes to form metalloformyl, (TMTAA)Rh-CHO, and $\alpha$-hydroxyalkyl complexes, (TMTAA)Rh-CH(R)OH (equations 6-8). [(TMTAA)Rh $]_{2}$ also reacts with $\mathrm{CO}$ to form a dimetalketone

6) $\left[(\text { TMTAA) } \mathrm{Rh}]_{2}+\mathrm{H}_{2} \rightleftharpoons 2(\mathrm{TMTAA}) \mathrm{Rh}-\mathrm{H}\right.$

7) (TMTAA)Rh-H + $\mathrm{CO} \rightleftharpoons$ (TMTAA)Rh-CHO

8) $\left(\right.$ TMTAA) $\mathrm{Rh}-\mathrm{H}+\mathrm{H}_{2} \mathrm{CO} \rightleftharpoons($ TMTAA $) \mathrm{Rh}-\mathrm{CH}_{2} \mathrm{OH}$

(TMTAA)Rh-C(O)-Rh(TMTAA) (equation 9), but does not form a dimetal $\alpha$-diketone complex $(\mathrm{M}-\mathrm{C}(\mathrm{O}) \mathrm{C}(\mathrm{O})-\mathrm{M})$ in observable concentrations at up to 30 atmospheres pressure of $\mathrm{CO}$. TMTAA

$$
\text { 9) }[(\text { TMTAA }) \mathrm{Rh}] 2+\mathrm{CO} \rightleftharpoons(\text { TMTAA)Rh-C(O)-Rh(TMTAA) }
$$

has smaller steric demands than porphyrins, and this observation supports our model that substantial formation of a dimetal $\alpha$-diketone depends on relief of steric effects in the dimetal ketone. The dianion of (TMTAA) is antiaromatic 16 pi electron ligand. The similarity of the reactivity of the $\mathrm{Rh}$ (II) and $\mathrm{Rh}-\mathrm{H}$ derivatives with rhodium porphyrins illustrates that the aromatic pi electron structure of porphyrins is not an essential feature for the unusual $\mathrm{M}-\mathrm{H}$ and $\mathrm{M}-\mathrm{C}$ bond enthalpies associated with rhodium porphyrins. This is an important result for our continuing studies because it suggests that many related ligand arrays may yield rhodium complexes with the appropriate thermodynamic parameters needed to produce formyl complexes from reaction with $\mathrm{H}_{2}$ and $\mathrm{CO}$.

\section{4) Reactions of isocyanides with (por)Rh (II) and (por)Rh-H complexes}

Isocyanides have similar electron structures and reactivity patterns but generally enhanced reactivity when compared to carbon monoxide and are used to model and define the range of potential carbon monoxide reactivity. The reactions of carbon monoxide with (por) $\mathrm{Rh}$ (II) complexes give a 1:1 CO adduct, a dimetallo ketone and a dimetallo diketone in an equilibrium distribution. Alkyl isocyanides react with (por) $\mathrm{Rh}$ (II) species to form 1:1 complexes and subsequent $\mathrm{N}-\mathrm{R}$ bond cleavage to yield (por)Rh-CN and (por) Rh-R complexes in equal quantities as the exclusive products $(\mathrm{R}=\mathrm{Me}, \mathrm{n}-\mathrm{Bu})$. The reaction occurs in the time of mixing for (TMP)Rh and proceeds in a few hours with $[(\mathrm{OEP}) \mathrm{Rh}]_{2}$ which suggests the importance of metalloradicals in the process. No evidence was found for bridging isocyanide complexes that 
would be analogous to the dimetal ketone and dimetal $\alpha$-diketone species observed for $\mathrm{CO}$ reactions with (por) $\mathrm{Rh}^{\mathrm{II}}$ species undoubtedly due to steric effects of the isocyanide alkyl group.

The N-R bond breaking probably occurs by a radical process where the isocyanide coordinates to (por) Rh which is attacked by a second metalloradical to form Rh-CN and Rh-R bonds in a concerted step. The proposed transition state is similar to that suggested for the

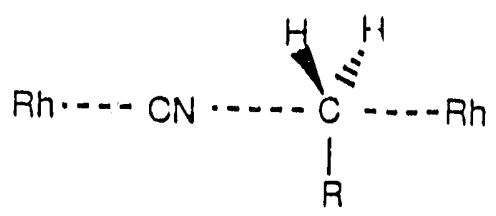

activation of methane by (TMP)Rh .

(OEP) Rh-H was anticipated to react with isocyanides to yield metalloformimidoyl complex in analogy with the $\mathrm{CO}$ reaction that forms (OEP)Rh-CHO (equation 10). Methyl isocyanide and $\mathrm{n}$-butyl isocyanide do yield the corresponding formimidoyl compounds but the system reacts further to produce the alkyl and cyanide complexes associated with $\mathrm{CN}-\mathrm{R}$ bond cleavage (equation 11). Using the sterically hindered and rigid 2,6-xylyl isocyanide results in exclusive

10) (OEP) $\mathrm{Rh}-\mathrm{H}+\mathrm{CNR} \rightleftharpoons(\mathrm{OEP}) \mathrm{Rh}-\mathrm{CH}(\mathrm{NR})$

11) 2(OEP) Rh-H + CNR $\rightarrow$ (OEP) Rh-R + (OEP)Rh-CN + $\mathrm{H}_{2}$

formation of themetalloformimidoyl species without $\mathrm{N}-\mathrm{R}$ bond cleavage products (equation 12).

12)

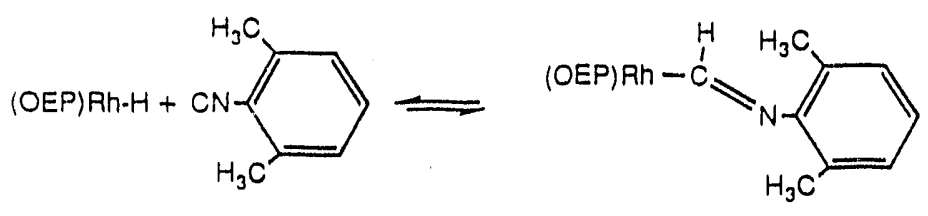

Addition of acid to the formimidoyl complex results in a signif: ant downfield shift of the porphyrin methyne hydrogen resonance indicating the formation of a cationic type compound, tentatively assigned to the Fischer carbene complex $[(\mathrm{OEP}) \mathrm{Rh}=\mathrm{CH}(\mathrm{NHR})]^{+}$. Related protonations of formyl complexes are currently being evaluated. 


\section{5) Metalloradical Reactions of Ethene}

Transition metal bonding and activation of alkenes by two electron processes occupies a prominent position in organometallic catalysis chemistry, ${ }^{32}$ but the potential of one-electron metalloradical reactions with alkenes remains relatively underdeveloped. A series of rhodium(II) porphyrin $\left(d^{7}, s=1 / 2\right)$ complexes where the ligand steric demands are incrementally increased has been used in studying metalloradical reactions of ethene. Tetramesitylporphyrinato rhodium(II), (TMP)Rh , and complexes with smaller ligand steric requirements react with ethene to form twocarbon alkyl bridged complexes, (por) $\mathrm{Rh}-\mathrm{CH}_{2} \mathrm{CH}_{2}-\mathrm{Rh}$ (por). Increasing the porphyrin steric demands by replacing the methyl substituents of TMP with ethyl and isopropyl groups results in rhodium(II) complexes that produce ethene coupling $\left(\mathrm{M}^{-} \mathrm{CH}_{2} \mathrm{CH}_{2} \mathrm{CH}_{2} \mathrm{CH}_{2}-\mathrm{M}\right)$, and permit observation of an intermediate metalloradical-ethene complex, [(por) $\left.\mathrm{Rh}\left(\mathrm{CH}_{2}=\mathrm{CH}_{2}\right)\right] \cdot$. EPR studies demonstrate that the intermediate contains an ethene that is bonded in an $\eta^{2}$ mode and further provides an unusually detailed experimental view of the interaction between an alkene and a metal center.

Alkene reactions of Rh(II) porphyrins that produce alkyl bridged complexes can be envisioned as occurring through the intermediacy of a metalloradical-alkene complex (equations 13-15). Interaction of a radical (X•) with ethene to form substantial concentrations of an alkyl radical $\left(\mathrm{X}-\mathrm{CH}_{2} \mathrm{CH}_{2} \cdot\right)$ requires an $\mathrm{X}-\mathrm{CH}_{2}$ bond dissociation enthalpy of approximately $72 \mathrm{kcal}$ $\mathrm{mol}^{-1}$.

13) (por)Rh・ $+\mathrm{CH}_{2}=\mathrm{CH}_{2} \rightleftharpoons\left[(\right.$ por $\left.) \mathrm{Rh}\left(\mathrm{CH}_{2}=\mathrm{CH}_{2}\right)\right] \cdot$

14) $\left[(\right.$ por $\left.) \mathrm{Rh}\left(\mathrm{CH}_{2}=\mathrm{CH}_{2}\right)\right] \cdot+\cdot \mathrm{Rh}$ (por) $\rightleftharpoons$ (por) $\mathrm{Rh}-\mathrm{CH}_{2} \mathrm{CH}_{2}-\mathrm{Rh}$ (por)

15) $2\left[\right.$ (por) $\left.\mathrm{Rh}\left(\mathrm{CH}_{2}=\mathrm{CH}_{2}\right)\right] \bullet$ (por) $\mathrm{Rh}-\mathrm{CH}_{2} \mathrm{CH}_{2} \mathrm{CH}_{2} \mathrm{CH}_{2}-\mathrm{Rh}$ (por)

Metalloradical reactions of (por) Rh• species with alkenes differ from alkyl radical reactions in that the (por) Rh- $\mathrm{CH}_{2}$ bond dissociation enthalpy $\left(\sim 50 \mathrm{kcal} \mathrm{mol}^{-1}\right)$ is insufficient to justify formation of an authentic carbon-based alkyl radical intermediate ((por) $\left.\mathrm{Rh}-\mathrm{CH}_{2} \mathrm{CH}_{2}{ }^{\circ}\right)$. Concerted formation of two $\mathrm{Rh}-\mathrm{CH}_{2}$ bonds is required for alkene reduction and this feature provides the opportunity to achieve selectivity for metalloradical reactions. The large steric demands of (TTEPP)Rh prohibit formation of a two-carbon bridged complex and the reaction proceeds to give a four-carbon alkene coupling product ((por) $\mathrm{Rh}-\left(\mathrm{CH}_{2}\right)_{4}-\mathrm{Rh}$ (por)) which relieves the steric congestion. Alkene oligomerization stops at the dimer because further radical reaction requires homolysis of a relatively strong $\mathrm{Rh}-\mathrm{CH}_{2}$ - bond. We are currently evaluating reactions for a wide variety of metalloradicals and alkenes in an effort to determine the generality and efficacy for this type of controlled radical process. 


\section{6) Metalloradical Reactions with $\mathrm{H}_{2}$ and $\mathrm{D}_{2}$}

Metal catalyzed hydrogenation of substrates involves addition of hydrogen to the metal center as an obligatory step. ${ }^{33}$ The importance of this class of reactions has stimulated efforts to understand the scope of mechanistic pathways operative in reactions of $\mathrm{H}_{2}$ with metal complexes. As part of our program to evaluate the metalloradical reactions of rhodium(II) macrocycles with substrates like $\mathrm{CH}_{4}, \mathrm{CO}, \mathrm{CH}_{2}=\mathrm{CH}_{2}$, we have studied the reactions of (TMP)Rh $\bullet$ with $\mathrm{H}_{2}$ and $\mathrm{D}_{2}{ }^{34}$

Benzene solutions of (TMP)Rh• $\left(\sim 5 \times 10^{-4} \mathrm{M}\right)$ react with $\mathrm{H}_{2}\left(\mathrm{P}_{\mathrm{H}_{2}}=0.2-1.0 \mathrm{~atm}\right.$.) to form the hydride complex, (TMP)Rh-H (equation 16). Reaction 16 is well suited for kinetic studies

\section{6) $2(\mathrm{TMP}) \mathrm{Rh} \bullet+\mathrm{H}_{2} \rightleftharpoons 2(\mathrm{TMP}) \mathrm{Rh}-\mathrm{H}$}

because it is free from any competitive processes such as solvent reactions, M-M bond formation, and hydrogenation of the ligand, which have complicated previous studies of $\mathrm{H}_{2}$ reactions with metalloradicals. The rate for reaction 16 is observed to have a second-order dependence on the molar concentration of (TMP)Rh - first-order rate dependence on the molar concentration of $\mathrm{H}_{2}$ and an overall third order rate law for reaction $16\left(\right.$ rate $\left.(16)=k_{16}[(\mathrm{TMP}) \mathrm{Rh} \cdot]^{2}\left[\mathrm{H}_{2}\right]\right)$. Temperature dependence of the third order rate constant $\left(k_{16}\right)$ was used in deriving estimates for the transition state and Arrhenius activation parameters $\left(\Delta \mathrm{H}_{(16)}^{\ddagger}\left(\mathrm{H}_{2}\right)=4.9 \mathrm{kcal} \mathrm{mol}^{-1}, \Delta \mathrm{S}_{(16)}^{\ddagger}\left(\mathrm{H}_{2}\right)=-40 \mathrm{cal} \mathrm{K}^{-1} \mathrm{~mol}^{-1}\right.$; $\left.A\left(H_{2}\right)=2.9 \times 10^{4}, \Delta E_{(16)}^{\ddagger}\left(H_{2}\right)=5.5 \mathrm{kcal} \mathrm{mol}^{-1}\right)$. Parallel studies for the reaction of $D_{2}$ with $(\mathrm{TMP}) \mathrm{Rh}$. provide the kinetic isotope effect on the rate $\left(k_{\left(\mathrm{H}_{2}\right)} / k_{\left(\mathrm{D}_{2}\right)}(296 \mathrm{~K})=1.6 ; k_{\left(\mathrm{H}_{2}\right)} / k_{\left(\mathrm{D}_{2}\right)}(353 \mathrm{~K})=\right.$ 1.3) and activation parameters $\left(\Delta \mathrm{H}_{(16)}^{\ddagger}\left(\mathrm{D}_{2}\right)=5.5 \mathrm{kcal} \mathrm{mol}^{-1}, \Delta \mathrm{S}_{(16)}^{\ddagger}\left(\mathrm{D}_{2}\right)=-39 \mathrm{cal} \mathrm{K}^{-1} \mathrm{~mol}^{-1}, \mathrm{~A}\left(\mathrm{D}_{2}\right)=\right.$ $\left.5.0 \times 10^{4}, \Delta \mathrm{E}_{(16)}^{\ddagger}\left(\mathrm{D}_{2}\right)=6.1 \mathrm{kcal} \mathrm{mol}^{-1}\right)$.

The rate law for reaction 16, $\left(\operatorname{rate}_{(16)}=k_{16}[(\mathrm{TMP}) \mathrm{Rh} \cdot]^{2}\left[\mathrm{H}_{2}\right]\right)$ establishes that the transition state contains two (TMP) Rh $\bullet$ metalloradicals and $\mathrm{H}_{2}$. A large negative activation entropy $\left(\Delta \mathrm{S}_{(16)}^{\ddagger}=\right.$ $\left.-40 \mathrm{cal} \mathrm{K}^{-1} \mathrm{~mol}^{-1}\right)$ and small activation enthalpy $\left(\Delta \mathrm{H}_{(16)}^{\ddagger}=4.9 \mathrm{kcal} \mathrm{mol}^{-1}\right)$ are also consistent with organizing three molecules into a transition state (TS) where evolution of two $\mathrm{Rh}-\mathrm{H}$ bonds substantially compensates for the $\mathrm{H}-\mathrm{H}$ bond breaking. Transition states of this general type have been previously implicated in reactions of dihydrogen with iodine atoms ${ }^{35}$ and cobalt(II) metalloradicals. ${ }^{36}$

\section{$\mathrm{Rh} \cdot \cdots \cdot \mathrm{H} \cdot \cdots \cdot \mathrm{H} \cdot \cdots \cdot \mathrm{Rh}$}

We have also recently invoked this type of TS for the reaction of methane with (TMP)Rh $\left(\mathrm{Rh} \cdot \bullet \mathrm{CH}_{3} \cdot \bullet \mathrm{H} \cdot \cdot \mathrm{Rh}\right)$ on the basis of the rate law (ratef $\left.=k_{\mathrm{f}}[(\mathrm{TMP}) \mathrm{Rh} \cdot]^{2}\left[\mathrm{CH}_{4}\right]\right)$, activation parameters $\left(\Delta S^{\ddagger}=-39 \mathrm{cal} \mathrm{K}^{-1} \mathrm{~mol}^{-1} ; \Delta \mathrm{H}^{\ddagger}=7.1 \mathrm{kcal} \mathrm{mol}^{-1}\right)$, and the kinetic isotope effect $\left.\left(k_{\left(\mathrm{CH}_{4}\right)} / k_{(\mathrm{CD}}\right)(296 \mathrm{~K})=8.2\right) .37$ 


\section{References}

1. (a) Dombek, B.D. Advances in Catalysis, 1983, 32, 325. (b) Rathke, J.W.; Feder, H.M. J. Am. Chem. Soc. 1978, 100, 3623. (c) Feder, H.M.; Rathke, J.W. Ann. N.Y. Acad. Sci., 1980, 333, 45. (d) Costa, L.C. Catal. Rev. Sci. Eng. 1983, 25, 325 .

2. (a) Fahey, D.R. J. Am. Chem. Soc. 1981, 103, 136. (b) Dombek, B.D. J. Am. Chem. Soc. 1981, 103, 6508. (c) Mehta, S.; Simmons, G.W.; Klier, K.; Herman, R.G. J. Catal. 1979, 57, 399. (d) Fleisch, T.H.; Mieville, R.L. J. Catal. 1984, 90, 165.

3. (a) Daroda, R.J.; Blackborow, J.R.; Wilkinson, G. J.C.S. Chem. Commun. 1980, 1098.

4. (a) Casey, C.P.; Andrews, M.A.; Rinz, J.E. J. Am. Chem. Soc. 1979, 101, 741. (b) Dombek, B.D.; Harrison, A.M. J. Am. Chem. Soc. 9183, 105, 2485. (c) Sweet, J.R.; Graham, W.A.G. J. Am. Chem. Soc, 1982, 104, 2811. (d) Steinmetz, G.R.; Geoffroy, G.L. J. Am. Chem. Soc. 1981, 103, 1278. (e) Gibson, D.H.; Owens, K.; Mandal, S.K.; Sattich, W.E.; Franco, J.O. Organometallics 1989, 8, 498.

5. (a) Gladysz, J.A. Adv. Organomet, Chem. 1982, 20, 1. (b) Gibson, D.H.; Owens, K.; Mandal, S.K.; Sattich, W.E.; Franco, J.O. Organometallics 1991, 10, 1203. (c) Gibson, D.H.; Owens, K.; Mandal, S.K.; Sattich, W.E.; Franco, J.O. Organometallics 1989, 8, 498.

6. Saussey, J.; Lavalley, J.C.; Lamotte, J.; Rais, T. J. Chem. Soc., Chem. Commun, $1984,278$.

7. Wayland, B.B.; Woods, B.A. J. Chem. Soc., Chem. Commun. 1981, 700.

8. (a) Wayland, B.B.; Woods, B.A.; Pierce, R.J. J. Am. Chem. Soc. 1982, 104, 302. (b) Wayland, B.B.; Duttahmed, A.; Woods, B.A. J. Chem. Soc, Chem. Commun. 1983, 142.

9. Wayland, B.B.; Woods, B.A.; Minda, V.M. J. Chem. Soc., Chem. Commun. 1982, 634.

10. Wayland, B.B.; Van Voorhees, S.L.; Wilker, C. Inorg. Chem. 1986, 25, 4039.

11. Wayland, B.B.; Van Voorhees, S.L. Organometallics 1985, 4, 1887.

12. Wayland, B.B.; Van Voorhees, S.L.; Del Rossi, K.J. J. Am. Chem. Soc, 1987, 109, 6513.

13. Coffin, V.L; Brennen, W.; Wayland, B.B. J. Am. Chem. Soc. 1988, 110, 6063.

14. Wayland, B.B.; Coffin, V.L.; Sherry, A.E. J. Am. Chem. Soc., Chem. Commun. 1989, 662.

15. Sherry, A.E.; Wayland, B.B. J. Am. Chem. Soc. 1989, 111, 5010.

16. Wayland, B.B.; Sherry, A.E.; Poszmik, G.; Bunn, A.G. J. Am. Chem. Soc. 1992, 114.

17. Wayland, B.B.; Sherry, A.E.; Coffin, V.L. "Activation of Carbon Monoxide by Metalloradicals," in "New Science in Homogeneous Transition Metal Catalyzed Reactions," W. Moser and D.W. Slocum, eds. Advances in Chemistry Series No. 230, chapter 10, American Chemical Society: Washington, D.C. 1992.

18. Bosch, H.W.; Wayland, B.B. J. Chem. Soc., Chem. Commun. 1986, 900.

19. Wayland, B.B. Polyhedron, 1988, 7, 1545.

20. Wayland, B.B.; Coffin, V.L.; Sherry, A.E.; Brennen, W.R. in "Bonding Energetics in Organometallic Compounds," T.J. Marks, Ed. ACS Symposium Series No. 428 American Chemical Society: Washington, D.C. 1990 , pp. 148-158. 
21. Wayland, B.B. in "Energetics of Organometallic Species," Martinho Simões Ed., Kluwer, 1992, pp. 69-74.

22. Van Yoorhees, S.L.; Wayland, B.B. Organometallics 1987, 6, 204.

23. Bunn, A.G.; Wayland, B.B. J. Am. Chem. Soc. 1992, 114.

24. Ford, P.C.; Rokicki, A. Adv. Organomet. Chem. 1988, 28, 139.

25. (a) Colton, R.; McCormick, M.J.; Pannan, C.D. Aust. J. Chem. 1978, 31, 1425-1438. (๖) Benner, L.S.; Balch, A.L. J. Am. Chem. Soc. 1978, 100, 6099-6106. (c) Kullberg, M.L.; Kubiak, C.P. Inorg. Chem. 1986, 25,26-30. (d) Lee, C.; James, B.R.; Nelson, D.A.; Hallen, R.T. Organometallics 1984, 3, 13601364. (e) Brown, M.P.; Puddephatt, R.J.; Rashidi, M.; Manojlovic-Mui., Lj.; Muir, K.W.; Slocum, T.; Seddon, K.R. Inorg. Chim. Acta 1977, 23, L223-L224. (f) Brown, M.P.; Puddephatt, R.J.; Rashidi, M.; Seddon, K.R. J. Chem. Soc., Dalton Trans. 1978, 1540-1544.

26. (a) Watkins, K.W.; Word, W.W Int. J. Chem. Kinet. 1974, 6, 855-873. (b) Anastasi, C.; Maw, P.L. J. Chem. Soc., Faraday Trans. 1 1982, 78, 2423. (c) O'Neal, H.E.; Benson, S.W. Thermochemistry of Free Radicals, Kocini, J.i.., Ed.; Wiley: New York, 1973; Vol. 2, Chapter 17.

27. Fairhurst, S.A.; Morton, J.R.; Preston, K.F. J. L hem. Phys. 1982, 77, 5872.

28. (a) Amatore, C.; Verpeaux, J.N.; Krusic, P.J. Organometallics 1986, 7, 2426. (b)Narayanan, B.A.; Amatore, C.; Kochi, J.K. Organometallics 1986, 5, 926.

29. Narayanan, B.A.; Kochi, J.K. J. Organomet. Chem. 1984, 272 , C49.

30. (a) Wayland, B.B.B.; Minliewicz, J.V.; Abd-Elmageed, M.E. J. Am. Chem. Soc. 1974, 96, 2795. (b) Hoffman, R.; Chen, M.M.L.; Thorn, D.L. Inorg. Chem. 1977, 16, 503. (c) Enemark, J.H.; Feltham, R.D. Coord. Chem. Rev. 1974, 13, 339.

31. (a) Ogoshi, H.; Setsume, J.; Yoshida, Z.J. Am. Chem. Soc. 1977, 99, 3869. (b) Paonessa, R.S.; Thomas, N.C.; Halpern, J. J. Am. CHem. Soc. 1985, 107, 4333. (c) Wayalnd, B.B.; Ba, S. Organometallics 1989, 8, 1438.

32. Collman, J.P.; Hegedus, L.S.; Norton, J.R.; Finke, R.G. Principles and Applications of Organotransition Metal Chemistry; University Science Books: Mill Valley, CA, 1987, pp. 523-617.

33. (a) James, B.R. Comprehensive Organometallic Chemistry; Wilkinson, G., Stone, F.G.A., Abel, E.W., Eds.; Pergamon: New York, 1982; Vol. 8, p 285. (b) Jardine, F.H. Prog. Inorg. Chem. 1981, 28, 63. (c) Faller, J.W. Homogeneous Catalysis with Metal Phosphine Complexes; Pignolet, L.H., Ed.; Plenum: New York, 1983; Chapter 2. (d) Collman, J.P.; Hegedus, L.S.; Norton, J.R.; Finke, R.G. Principles and Applications of Organotransition Metal Chemistry; University Science Books: Mill Valii y, CA, 1987; p 286.

34. Wayland, B.B.; Ba, S.; Sherry, A.E. Inor3. Chem. 1992, 31, 148.

35. Sullivan, J.H. J. Chem. Phys. 1967, 46, 73.

36. (a) Halpern, J. Inorg. Chim. Acta 1982, 62, 31. (b) Simandi, L.I.; Budo-Zahony, E.; Szvernyi, Z.; Memeth, S. J. Chem. Soc., Dalton Trans. 1980, 276. (c) Chao, T.H.; Espenson, J.H. J. Am. Chem. Soc. 1978, 100, 129.

37. (a) Sherry, A.E.; Wayland, B.B. J. Am. Chem. Soc. 1990, 112, 1259. (b) Wayland, B.B.; Ba, S.; Sherry, A.E. J. Am. Chem. Soc. 1991, 113, 5305. 
- Publications associated with DOE-FG02-86ER13615

"Organometallic Reactions of Rhodium Octaethylporphyrin Species in Pyridine: Heterolytic Cleavage of [(OEP)Rh $]_{2}$ and Metallo Anion Activation of CO," B.B. Wayland, K.J. Balkus, and M.D. Farnos, Organometallics, 1989, 8, 950.

"Thermodynamics for the Addition of $[(\mathrm{OEP}) \mathrm{Rh}]_{2}$ with Propene and Observation of a Facile Dyotropic 1,2 Exchange of (OEP)Rh Groups in (OEP) Rh- $\mathrm{CH}_{2} \mathrm{CH}\left(\mathrm{CH}_{3}\right)$ Rh(OEP)," B.B. Wayland, Y. Feng and S. Ba, Organometallics, 1989, 8, 1438.

"Metalloradical Activation of CO: Formation and Carbonyl Coupling of a Bent 17-Electron M-CO Unit," A.E. Sherry and B.B. Wayland, J. Am. Chem. Soc. 1989, 111, 5010.

"Selective Reductive Coupling of Carbon Monoxide," B.B. Wayland, V.L. Coffin and A.E. Sherry, J. Chem. Soc. Chem. Commun. 1989, 662.

"Thermodynamic Studies of the Hydrogenation and Reductive Coupling of Carbon Monoxide by Rhodium(II) Porphyrins," B.B. Wayland, V.L. Coffin, A.E. Sherry, and W.R. Brennen, in "Bonding Energetics in Organometallic Compounds," T.J. Marks, Ed. ACS Symposium Series No. 428, American Chemical Society: Washington, D.C. 1990, pp. $148-158$.

"Metalloradical Activation of Methane," A.E. Sherry and B.B. Wayland, J. Am. Chem. Soc., $9990,112,1259$.

"Formation and Reactivity of Tetramesitylporphyrinato Rhodium(II) Monocarbonyl: A Bent Rh(II) Complex that Reacts like an Acyl Radical," B.B. Wayland, A.E. Sherry, G. Poszmik and A.G. Bunn, J. Am. Chem. Soc. 1992, 114, 1673.

"Activation of Carbon Monoxide by Metalloradicals," B.B. Wayland, A.E. Sherry, and V.L. Coffin in "New Science in Homogeneous Transition Metal Catalyzed Reactions", W. Moser and D.W. Slocum, eds. Advances in Chemistry Series No. 230, chapter 10, American Chemical Socisty: Washington, D.C. 1992.

"Reactions of $\mathrm{H}_{2}\left(\mathrm{D}_{2}\right)$ with a Rhodium (II) Metalloradical: Kinetic Evidence for a FourCentered Transition State," B.B. Wayland, S. Ba and A.E. Sherry, Inorg. Chem. 1992, 31,148 .

"Rh-C Bond Dissociation Enthalpies for Organometallic Derivatives of Rhodium Porphyrins," B.B. Wayland in "Energetics of Organometallic Species," Martinho Simões Ed., Kluwer, 1992, pp. 69-74.

Papers accepted for publication

"One Electron Activation and Coupling of Ethylene by a RhII(Porphyrin): Direct Observation of an $\eta^{2}$-pi-Bonded Ethene-Metalloradical Complex," A.G. Bunn and B.B. Wayland, J. Am. Chem. Soc. 1992, 114.

Statement of Estimated Unobligated Balances DE-FG02-86ER13615

It is estimated that no funds will remain unexpended or uncommitted at the end of the current project period, December 14, 1992. 

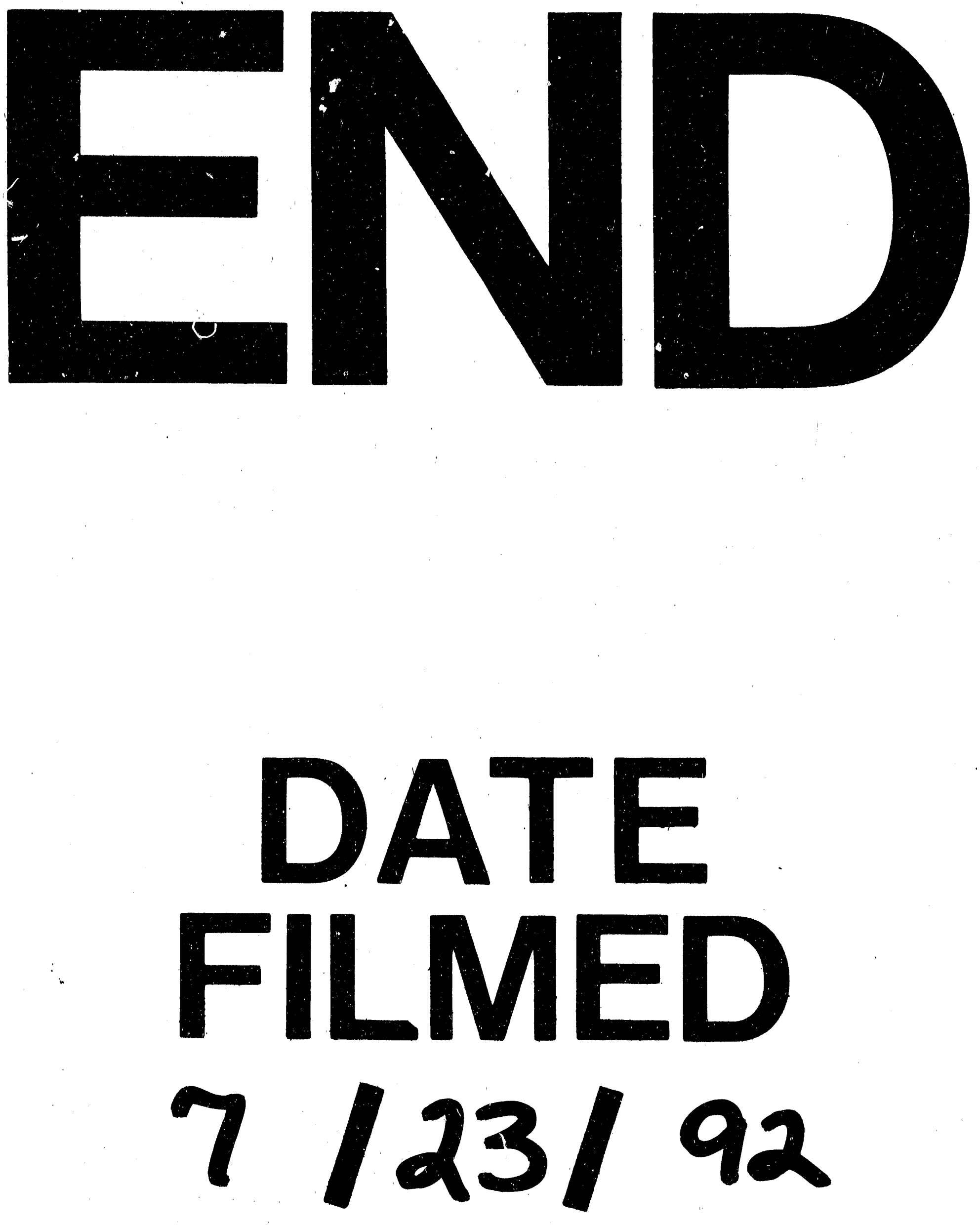
